Research Article

\title{
Studies on antioxidant activity of red, white, and black pomegranate (Punica granatum L.) peel extract using DPPH radical scavenging method
}

\author{
Uswatun Chasanah ${ }^{[1]^{*}}$ \\ ${ }^{1}$ Department of Pharmacy, Faculty of Health Science, University of Muhammadiyah Malangg, Malang, East \\ Java, Indonesia \\ Corresponding Author's Email: Uswatun@umm.ac.id
}

\begin{tabular}{ll} 
ARTICLE INFO & ABSTRACT \\
\hline $\begin{array}{l}\text { Article History } \\
\text { Received September 1,2020 }\end{array}$ & $\begin{array}{l}\text { Pomegranate (Punica granatum L.) has high antioxidant activity. In } \\
\text { Indonesia, there are red pomegranate, white pomegranate, and black } \\
\text { Revised January 7, 2021 } \\
\text { pomegranate. The purpose of this study was to determine the antioxidant }\end{array}$ \\
$\begin{array}{l}\text { Published February 1,2021 } \\
\text { activity of red pomegranate peel extract, white pomegranate peel extract, } \\
\text { and black pomegranate peel extract. The extracts prepared by ultrasonic }\end{array}$ \\
$\begin{array}{l}\text { Keywords } \\
\text { maceration in 96\% ethanol, then evaporated until thick extract was }\end{array}$ \\
$\begin{array}{l}\text { obtained and its antioxidant activity was determined using the DPPH } \\
\text { Black pomegranate } \\
\text { Red pomegranate }\end{array}$ & $\begin{array}{l}\text { radical scavenging method. This study showed that all pomegranate peel } \\
\text { extract varieties have potent antioxidant activity and the black } \\
\text { pomegranate peel extract has the highest antioxidant power. }\end{array}$
\end{tabular}

granate

Peel extract

$\mathrm{DPPH}$

Doi

10.22219/farmasains.v5i2.13472

\section{INTRODUCTION}

Pomegranate (Punica granatum L.) belongs to the Puricaceae family, a plant originating from the Middle East (Rana, Narzary \& Ranade, 2010). All parts of the pomegranate, such as fruit (fruit juice, fruit seeds, peel fruit), leaves, flowers, roots, and bark, have therapeutic effects such as neuroprotective, antioxidant, repair vascular damage, and anti-inflammatory. The clinical application of this plant used in cancers, atherosclerosis, hyperlipidemia, carotid artery stenosis, myocardial perfusion, periodontal disease, bacterial infections, ultraviolet radiation, erectile dysfunction, male infertility, neonatal hypoxic-ischemic brain injury, Alzheimer's disease, and obesity (Jurenka, 2008; Mackler, Heber \& Cooper, 2013). it is also used as cosmetic ingredients (Aslam, Lansky \& Varani, 2006). The bioactive contained in the pomegranate peel is triterpenoids, steroids, glycosides, flavonoids, tannins, carbohydrate \& Vitamin C. Much of bioactivity pomegranate peel and one of them is antioxidant activity (Derakhshan et al., 2018).

There are red pomegranate, white pomegranate, and purple/black pomegranate. Red pomegranate has a sweeter and fresher taste, white pomegranate more chewy and coarse and less sweet, and black pomegranate has a sweeter flavor than this red variety. Interested in the three varieties of pomegranate, a study will be conducted to compare the ethanol extract's antioxidant activity of red pomegranate peel, white and black pomegranate peel. 


\section{MATERIALS AND METHODS}

\section{Material}

The materials used in this study was red, white, and black pomegranate from Situbondo, East Java, Indonesia, ethanol (technical grade), methanol (pro analysis, MERCK $^{\odot}$ ), 2,2-Diphenyl-1-picrylhydrazyl (SigmaAldrich $^{\odot}$ ), ascorbic acid (CSPC Weisheng Pharmaceutical (Shijiazhuang) Co. Ltd. ${ }^{\odot}$ )

\section{Instruments}

This study's instruments were ultrasonic bath, rotary vacuum evaporator, Universal oven memmert UN 75, and Spectrophotometer UV-VIS (Shimadzu).

\section{Methods}

\section{Preparation of Pomegranate Peel Extract}

Fresh pomegranate fruit was harvested from Situbondo, East Java, Indonesia, in December 2019. The peels of fruit that had cut pieces dan cleaned were drying at $40^{\circ} \mathrm{C}$ for three days and then crushed into powder. As much as $50 \mathrm{gr}$ of red, white, and black pomegranate peel powder (mesh 60) extracted by ultrasonic macerated for 45 minutes at an amplitude of $20-40 \mathrm{~Hz}$ in $96 \%$ ethanol using the ratio of 1:10 (pomegranate:solvent) (Baihaqi, Budiastra \& Darmawati, 2018). The extract was pressed, filtered, and the ethanol removed by a rotary vacuum evaporator. Furthermore, the remaining ethanol was evaporated in the oven for three days at $40^{\circ} \mathrm{C}$ until a thick consistency was obtained.

\section{Evaluation of Antioxidant Activity by DPPH Radical Scavenging Method}

Free radical scavenging activity of red, white, and black pomegranate cortex was measured by the DPPH method (Molyneux P, 2004; Alam, Bristi \& Rafiquzzaman, 2013). The $200 \mu \mathrm{g} / \mathrm{mL}$ solution of DPPH in methanol, $20 \mu \mathrm{g} / \mathrm{mL}$ solution of extract in methanol, and ascorbic acid solution of $20 \mu \mathrm{g} / \mathrm{mL}$ in methanol were prepared. The $1.0 \mathrm{~mL}$ of DPPH solution added to $0.5 ; 1.0 ; 2.0 ; 3.0 ; 4.0$; and $5.0 \mathrm{~mL}$ of extract solution or ascorbic acid, as standard sample, then added methanol to $10.0 \mathrm{~mL}$. The mixture was shaken vigorously and allowed to stand at $37^{\circ} \mathrm{C}$ for 30 minutes, then absorbance is measured at 514-515 nm by a spectrophotometer UV-VIS. The lower absorbance of the sample indicated a higher free radical activity. The percentage of inhibition calculated by the following equation:

Percentage Inhibition $=\left(A_{0}-A_{1} / A_{0}\right) \times 100$

$A_{0} \quad=$ absorbance of the control reaction

$A_{1} \quad=$ absorbance in the presence of a test or standard sample.

An inhibitor concentration of $50 \%\left(I_{50}\right)$ is used to express the activity of the antioxidant. The sample's $\mathrm{IC}_{50}$ was defined as the concentration of the sample required to reduce DPPH free radical by as much as $50 \%$. The linear regression equation is used from the extract's concentration range to the immersion \% DPPH to determine the extract concentration that reduces $50 \%$ of DPPH. The value of $50 \%$ was obtained from the $x$ value after substituting $y=50$. From the equation $y=a+b x$, the IC50 value calculated using the following formula:

$$
1 C_{50}=(50-a) / b
$$

A comparison of the $\mathrm{IC}_{50}$ value of pomegranate peel extract and ascorbic acid to determine the pomegranate peel extract sample's antioxidant activity.

Data Analysis

From the gradient of the Linear inhibition curve determined of $\mathrm{IC}_{50}$, then it is analyzed using One-way Anova with a degree of confidence of $95 \%$.

\section{RESULTS AND DISCUSSIONS}

\section{The Pomegranate Peel Extract}

The pomegranate peel extracts obtained (Figure 1), are a thick dark extract sequentially from the white, red, and black pomegranate peel extracts, which have an increasingly dark color intensity. 


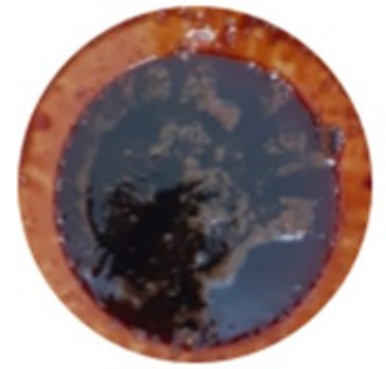

A

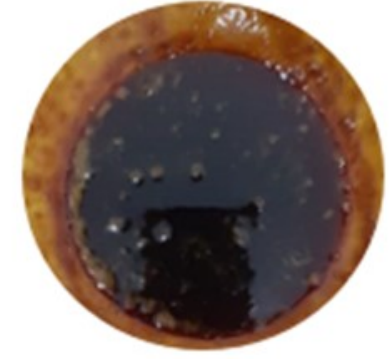

B

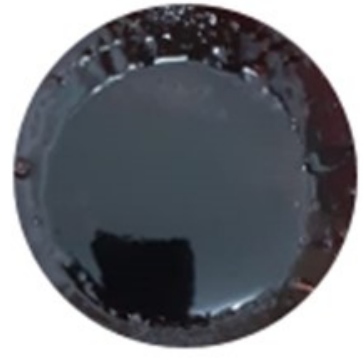

C

Figure 1. Red (A), white (B), and black pomegranate peel extract (C).
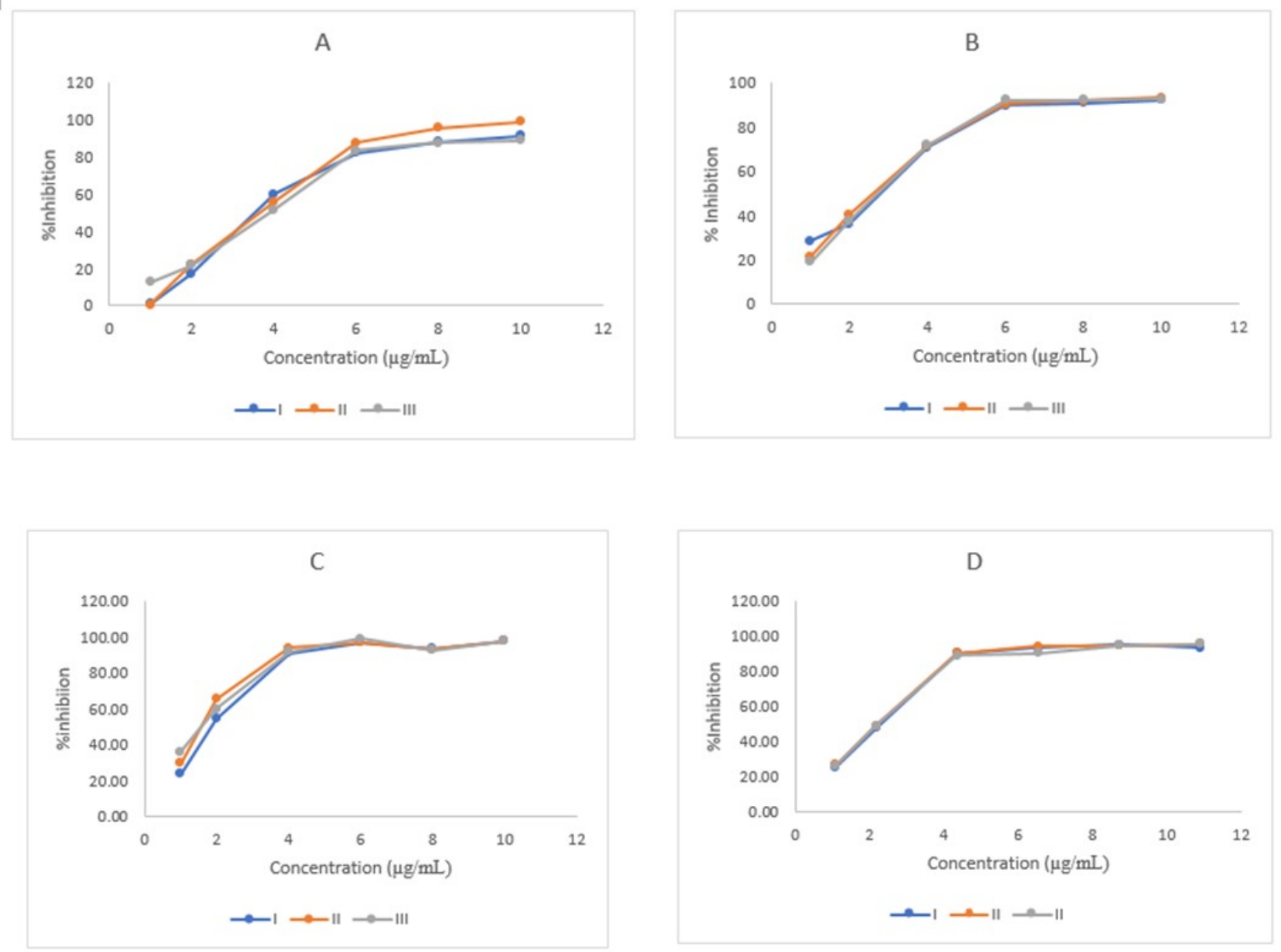

Figure 2. This figure is the Percentage inhibition of red pomegranate peel extract (A), white pomegranate peel extract (B), black pomegranate peel extract (C), and Ascorbic acid as a control (D).

The bioactive contained in the pomegranate peel is triterpenoids, steroids, glycosides, flavonoids, tannins, carbohydrate, and vitamin C. The peel's brilliant red color is attributed to anthocyanidins and flavan-3-ol (Bhandary, Kumari, Bhat, Sharmila \& Beka, 2012). From the intensity of the color obtained, black pomegranate may have the highest anthocyanidins and flavan-3-ols.

\section{Antioxidant Activity}

The results of determining the maximum wavelength achieved by the DPPH solution in methanol are 514 $515 \mathrm{~nm}$. The percentage inhibition of the red, white, and black pomegranate peel extract is shown in Figure 2. The gradient obtained from this curve was used to determine $I C_{50}$ of pomegranate peel extract (Table 1 ).

The sample concentration of red, white, and black pomegranate peel extract made of 1.0;2.0;4.0;6.0;8.0; 
Table 1. The IC50 of pomegranate peel extract

\begin{tabular}{|c|c|c|c|c|c|}
\hline \multirow{2}{*}{ Pomegranate } & \multicolumn{3}{|c|}{ IC $50(\mu \mathrm{g} / \mathrm{mL})$ Replication } & \multirow{2}{*}{ Mean of IC50 $(\mu \mathrm{g} / \mathrm{mL})$} & \multirow[t]{2}{*}{$\mathrm{SD}(\mu \mathrm{g} / \mathrm{mL})$} \\
\hline & I & II & III & & \\
\hline Red pomegranate & 3.88 & 3.78 & 3.80 & 3.82 & 0.05 \\
\hline White pomegranate & 2.75 & 2.82 & 2.89 & 2.82 & 0.07 \\
\hline Black pomegranate & 2.02 & 1.69 & 1.63 & 1.78 & 0.21 \\
\hline Ascorbic acid & 2.30 & 2.25 & 2.27 & 2.27 & 0.02 \\
\hline
\end{tabular}

and $10.0 \mu \mathrm{g} / \mathrm{mL}$, as well as the concentration of ascorbic acid, too. Figure 2 shown the horizontal curve of the black pomegranate peel extract starts at a concentration of $4.0 \mu \mathrm{g} / \mathrm{mL}$; the same thing is shown by the ascorbic acid curve, while the red and white pomegranate peel extract the horizontal curve line starts at a concentration of $6.0 \mu \mathrm{g} / \mathrm{mL}$. The $\mathrm{IC}_{50}$ obtained from the gradient concentration of this curve; therefore, the $\mathrm{IC}_{50}$ calculation of black pomegranate peel extract and vitamin $C$ uses a concentration of 1.0;2.0; and $4.0 \mu \mathrm{g} / \mathrm{mL}$., while red and white pomegranate peel extract uses a concentration of 1.0;2.0;4.0; and $6.0 \mu \mathrm{g} / \mathrm{mL}$.

The $\mathrm{IC}_{50}$ of red, white, and black pomegranate peel extract is $3.82 ; 2.82$; and $1.78 \mu \mathrm{g} / \mathrm{mL}$, while ascorbic acid as control has an $\mathrm{IC}_{50}$ is $2.27 \mu \mathrm{g} / \mathrm{mL}$. The $\mathrm{IC}_{50}$ of all pomegranate peel extract is less than $50 \mu \mathrm{g} / \mathrm{mL}$, so that their antioxidant activity is very strong. The $\mathrm{IC}_{50}$ of black pomegranate peel extracts less than ascorbic acid. Otherwise, red and white pomegranate pell extract having an $\mathrm{IC}_{50}$ more than ascorbic acid. The highest score of $\mathrm{IC}_{50}$ was owned by black pomegranate, followed by white and red pomegranate. This result, contrary to the research conducted by Andriyani \& Suharyanto (2015), that reported the antioxidant activity of black pomegranate has the highest score followed by red and white pomegranate. The pomegranate peel ethanolic extract contained flavonoids, tannins, and carbohydrates (Bhandary et al., 2012). The pomegranate peel's flavonoids with antioxidant activity are catechin, cyanidin, kaempferol, luteolin, quercetin, and rutin, while significant pomegranate tannins peel is casuarinin, methyl gallate, granatin A, granatin B, pedunculagin, punicalagin, and punicalin (Middha, Usha \& Pande, 2013). Further research is needed to determine the total content of flavonoids and tannins from red, white, and black pomegranate peel.

\section{CONCLUSIONS}

The antioxidant activity of red pomegranate pell, white pomegranate peel, and black pomegranate peel are potent.

\section{ACKNOWLEDGMENT}

author is truly grateful to the University of Muhammadiyah Malang that funding this research and Abidatussoleha, Trisma Zulita Sari, Graceia Yuanata Putri, Hera Nadila Pertiwi, Fella Febriana, Nanda Trisna Olivia, and Muhammad Aspin Hadiyani for their help carry out this research.

\section{REFERENCES}

Alam, M. N., Bristi, N. J., \& Rafiquzzaman, M. (2013). Review on in vivo and in vitro methods evaluation of antioxidant activity. Saudi Pharmaceutical Journal, 21(2), 143-152. doi:10.1016/j.jsps.2012.05.002

Andriani, V. and Suharyanto. (2015). Karakterisasi Anatomi dan Aktivitas Antioksidan Delima (Punica granatum L.) (Master Thesis). Universitas Gajah Mada, Yogyakarta, Indonesia. Retrieved from http:// etd.repository.ugm.ac.id/home/detail_pencarian/89446

Aslam, M. N., Lansky, E. P., \& Varani, J. (2006). Pomegranate as a cosmeceutical source: Pomegranate fractions promote proliferation and procollagen synthesis and inhibit matrix metalloproteinase-1 production in human skin cells. Journal of Ethnopharmacology, 103(3), 311-318. doi:10.1016/j.jep.2005.07.027

Baihaqi, Budiastra, I. W., \& Darmawati, E. (2018). Peningkatan Efektivitas Ekstraksi Oleoresin Pala Menggunakan Metode Ultrasonik. Jurnal Keteknikan Pertanian, 6(3), 249-254. doi:10.1017/CBO9781107415324.004

Bhandary, S., Kumari, S., Bhat, V., Sharmila, K., \& Beka, M. (2012). Preliminary phytochemical screening of various extracts of Punica granatum peel, whole fruit and seeds. Nitte University Journal of Health Science, 2(4), 35-38. doi:10.1055/s-0040-1703609 
Derakhshan, Z., Ferrante, M., Tadi, M., Ansari, F., Heydari, A., Hosseini, M. S., ... Sadrabad, E. K. (2018). Antioxidant activity and total phenolic content of ethanolic extract of pomegranate peels, juice and seeds. Food and Chemical Toxicology, 114, 108-111. doi:10.1016/j.fct.2018.02.023

Jurenka, J. (2008). Therapeutic applications of pomegranate (Punica granatum L.): A review. Alternative Medicine Review, 13(2), 128-144.

Mackler, A. M., Heber, D., \& Cooper, E. L. (2013). Pomegranate : Its Health and Biomedical Potential. EvidanceBased Complementary and Alternative Medicine, 2013, 903457. doi:10.1155/2013/903457

Middha, S. K., Usha, T., \& Pande, V. (2013). A Review on antihyperglycemic and antihepatoprotective activity of eco-friendly punica granatum peel waste. Evidence-Based Complementary and Alternative Medicine, 2013, 656172. doi:10.1155/2013/656172

Molyneux P. (2004). The use of the stable free radical diphenylpicryl-hydrazyl (DPPH) for estimating anti-oxidant activity. Songklanakarin Journal of Science and Technology, 26(2), 211-219.

Rana, T., Narzary, D., \& Ranade, S. A. (2010). Systematics and taxonomic disposition of the genus Punica L. Pomegranate. Fruit, Vegetable and Cereal Science and Biotechnology, 4(2), 19-25. 